\title{
KOGESIN VAPUSTUST VÕI VAPUSTUSER SIHILISED VERBID VALIKUTE EES
}

\author{
Natalia Vaiss
}

Ülevaade. Toetudes eesti keele ühendkorpuse materjalidele, tutvustatakse artiklis regulaarset (lause aspektist sõltuvat) ja ebaregulaarset (ka/või muudest teguritest sõltuvat) objekti vormivaheldust ja seda võimaldavaid, aspektverbidena käituvaid verbe. Regulaarsena käsitletakse aspektverbide või nende eritähendus(t)e) ning modifitseerivate elementide tõttu aspektverbidena käituvate partitiiv- ja perfektiivverbide aspekti eristavat käändevaheldust. Ebaregulaarsuse juhtumitest on vaatluse all püsiühendi struktuurist tingitud, verbi tähendusi eristav, neutraalset aspekti tähistav ja objektfraasi leksikaalsemantilisest koosseisust sõltuv käändevaheldus.

Võtmesõnad: aspekt, transitiivsus, sihitis, eesti keel

\section{Sissejuhatus}

Eesti keele transitiivseid verbe on vastavalt neid laiendava objekti vormivõimalustele jaotatud partitiiv-, aspekt- ja perfektiivverbideks (vt nt EKG II, Erelt 2017c, Metslang 2017), kuid see jagunemine on paraku üsna tinglik ning tekitab paratamatult siirderühmi (vt Pool 2007, Vaiss 2004, Tamm 2012, Tamm, Vaiss 2019). Nii võimaldavad lisaks aspektverbidele ka paljud partitiiv- ja perfektiivverbid teatud tingimustel aspekti eristavat objekti käändevaheldust ning moodustavad seega süntaktilises mõttes aspektverbide allrühmi. Lisaks on paljud eesti keele verbid polüseemsed ning nende eri tähendused ja eri kasutused tingivad erinevaid süntaktilisi malle.

Artikli eesmärk on täiendada senist teadmist objekti vormivahelduse teguritest. Verbe, mille puhul objekti vormivaheldust esineb, käsitlen kui aspektverbe või aspektverbidena käituvaid verbe. Lähenemise uudsus seisneb katses eristada objekti regulaarset ja ebaregulaarset käändevaheldust: esimese põhiülesandeks on aspekti väljendamine, teine aga on tingitud ennekõike muudest asjaoludest, nagu verbi tähenduserisused või püsiühendi struktuur. Objekti vormivahelduse kahe tüübi eristamine tundub otstarbekas mitte ainult eesti keele süsteemi täpsemaks 
kirjeldamiseks, vaid ka rakenduslikust vaatenurgast, nagu eesti keele kui teise või võõrkeele õppe, leksikograafia ja masintõlke jaoks.

Analüüs on kvalitatiivne ja põhineb korpusematerjalis leidunud objektikollokatsioonide vaatlemisel. Näitematerjalina kasutan eesti keele ühendkorpuse 2017. aasta versiooni $\left(\mathrm{ENC}_{17} \mathrm{7}^{1}\right)$ lauseid või selle korpuse materjalil põhinevaid lauseid. Ühendkorpus on suurim eesti keele korpus, mis sisaldab üle ühe miljardi tekstisõna ning mis tänu otsingumootori Sketch Engine (vt Kilgarriff jt 2004) funktsioonile WordSketch võimaldab näha verbide sagedamaid kollokatsioone (sh objektikollokatsioone). Korpus sisaldab üheksa allkorpust, mis loob võimaluse analüüsida verbide leksikaalseid ja grammatilisi omadusi, mis ilmnevad paljudes eri tüüpi tekstides ja erinevates allkeeltes (ajakirjandus-, ilukirjandus- ja teaduskeel, populaarteaduslik ja ametlik keelekasutus, argisuhtlus).

Artikkel koosneb seitsmest osast. Esmalt tutvustatakse transitiivverbide partitiiv-, aspekt- ja perfektiivverbideks jagunemisega seotud seisukohti ja probleeme. 3. ja 4. osa on pühendatud regulaarse ja ebaregulaarse objekti käändevahelduse näidete detailsele kirjeldamisele, toetudes eeskätt üldreeglitele alluva objektiga finiitsete jaatavate lausete analüüsile. 5. osas tutvustatakse korpusematerjalis ilmnevaid objektirektsiooninihkeid ning 6. osas vaadeldakse objekti vormi varieerumist korpusematerjalis kahe sagedase verbi, tüüpiliselt partitiivverbina esineva hammustama ja tüüpilise perfektiivverbi ostma näitel. Viimane osa esitab kokkuvõtteid ja järeldusi.

\section{Partitiiv-, aspekt- ja perfektiivverbid ning kõrvalekalded põhireeglist}

Verbe on sõltuvalt nende semantikast, sealhulgas ka aspektuaalsest tähendusest, liigitatud mitmeti (nt Vendler 1967, Pihlak 1985, Tommola 1986, Levin 1993, Askonen 2001, Van Valin 2005, Tragel, Taremaa 2019). Eesti keele transitiivverbide puhul on tavalised objektirektsioonist lähtuvad kolmik- või nelikjaotused, mis põhinevad nii sihitiserektsioonil kui tähendusel (vt Pool 2007: 28-36). Tavaliselt eristatakse kolme rühma: partitiiv-, aspekt- ja perfektiivverbe.

\subsection{Partitiivverbid}

Partitiivverbid on verbid, mida laiendav objekt saab olla ainult partitiivis. Need verbid väljendavad piirivõimaluseta tegevust, kestusega sündmust või seisundit (EKG II 1993: 49-50). Seepärast on viimastes grammatikakäsitlustes partitiivverbe nimetatud ka piiritlusaspekti väljendamise seisukohalt imperfektiivseteks verbideks (Erelt 2017c: 113, Metslang 2017: 264). Samas kuulub partitiivverbide hulka väga mitmekesise semantikaga verbe (vt EKG II). Osa neist väljendab tõepoolest üldjuhul vaid kestvat ja piiritlemata (imperfektiivset) tegevust, nt austama, jätkama: Ta austab oma vanemaid, Ta jätkas oma õpinguid ülikoolis. Osa partitiivseid verbe väljendab aga mittekestvat ja piiritletud (perfektiivset) tegevust, nt tervitama, alustama, tutvustama: Ta tervitas oma naabrit; Anna kohe märku, kui auto 
alustab sõitu; Tutvusta mulle oma venda. See on üks põhjustest, miks eesti keele kui teise keele õppijatel on raskusi partitiivverbide äratundmisega ja nad võivad kasutada koos nendega totaalobjekti (vt nt Pool 2007).

Lisaks on täheldatud, et mõnel partitiivverbiks loetud tegusõnal võib olla mitu objektirektsiooni (vrd Vormsit asustasid kunagi rootslased, Rootslased asustasid saare) ning üsna paljud partitiivverbid lubavad teatud tingimustel totaalobjekti, nt määratleva täiendi (ôppis luuletust, óppis ilusa $\sim$ ühe luuletuse) ${ }^{2}$ ja piiritlevate laiendite lisamisel (Vaiss 2004, Tamm, Vaiss 2019).

Perfektiveerivate ehk piiritlevate elementide kõige tuntumaks näiteks on veeretama-tüüpi siirdamist väljendavaid verbe laiendavad latiivsed kohamäärused, mille lisamisega võimaldatakse nii piiritlemata kui ka piiritletud olukorda (Mehed veeretasid vaati, Mehed veeretasid vaati vaadi õue) (Rätsep 1978: 221). Samamoodi lisavad piiritletust ka separatiivsed koha- ja valdajamäärused (Peeter õppis meistrilt ameti) ja mitmesugused latiivsed koha-, valdaja- ja seisundimäärused (udu halvendas nähtavuse miinimumini; sõidutas mehed rahajärele; ahvatles sõpra sõbra kuriteole $\sim$ kuritegu sooritama; hoidis leiva lapse jaoks; lakkis põranda säravaks särama; ihus nuga noa teravaks; nihutas ukse praokile) (Rätsep 1978, Klaas 1999, Vaiss 2004). Selliseid piirivõimalusega partitiivverbe on vaadeldud eesti keele transitiivverbide eri rühmana ja nimetatud mitmeti: kahesuguse objektikasutusega verbid (Rätsep 1978), pehmed partitiivverbid (Klaas 1999), irresultatiivverbid (Tauli 1980), nõrgad aspektverbid (Mati Erelt oma õppetöös kasutatud liigituses, mida mainib Pool 2007: 34), potentsiaalselt aspektilised partitiivverbid (Vaiss 2004). Piiritlevate laiendite olemasolul sarnanevad need verbid tõepoolest süntaktiliselt pigem aspekt- kui partitiivverbidega, mis peaksid ju esinema vaid partitiivobjektiga.

\subsection{Aspekt- ja perfektiivverbid}

Aspektverbe (vt EKG II: 50-51) on viimastes grammatikakäsitlustes nimetatud ka imperfektiiv-perfektiivseteks verbideks (Erelt 2017c: 114. Metslang 2017: 264), kuna need võivad väljendada nii piiritlemata kui ka piiritletud tegevust ja esineda vastavalt nii partitiiv- kui ka totaalobjektiga (ehitas suvilat suvila). Perfektiivverbide juures (nt ammendama, andestama,jätma, kaotama, leidma, saavutama, ostma; läbi lugema, ära jätma, ära arvama) on sihitis üldjuhul omastavas või nimetavas, kui lisaks piiritletud olukorrale on täidetud ka muud totaalobjekti tingimused (lause on jaatav ning objekt on kvantitatiivselt piiritletud) (Metslang 2017: 264). Samas võib mõne perfektiivse iseloomuga verbi puhul tegevuse piiritlematuks muutmiseks kasutada näiteks mas-tarindit (Kui ma teda viimati nägin, oli ta endale autot ostmas), aja- ja viisimäärusi aeglaselt, tasapisi, pikkamööda, järk-järgult, aina, alati, pidevalt, parajasti jms (Ta kaotab pidevalt oma prille) (Vaiss 2004). Niisiis on aspektverbidele omane piiritlusaspekti eristav objekti vormivaheldus võimalik ka perfektiivverbide puhul - tõsi küll, vaid leksikaalselt või grammatiliselt piiratud kontekstides.

\footnotetext{
2 Objektifraasis leiduvaid täiendeid on nimetatud ka leksikaalseteks markeriteks (Eslon 2012), samalaadseid täiendeid alusfraasis determinaatoriteks (Nemvalts 2000).
} 


\subsection{Põhireeglist erinev käändevaheldus}

Samas tuleb silmas pidada, et nii aspekt- kui perfektiivverbide puhul eristab objekti käändevaheldus piiritlusaspekti vaid jaatavas lauses kvantitatiivselt piiritletud objekti puhul, kuna kvantitatiivselt piiritlemata (ainesõna või ebamäärast hulka tähistav mitmuslik sihitis) ja eitava lause objekt on muudest teguritest sõltumata partitiivis (vt Metslang 2017: 266). Käändevahelduse põhireeglid kehtivad ennekõike finiitset verbivormi laiendava nimisõnalise objekti korral. Üldreeglitele ei allu isikulised (1. ja 2. isik) ja enesekohased asesõnad, mille puhul kasutatakse partitiivi ka piiritletud olukorras, kui üldreegli kohane oleks täissihitis (vrd Ta kutsus mind külla ja Ta kutsus sõbra külla). Fakultatiivselt võib pronoomenitega mina ma, sina $\sim$ sa, enese $\sim$ enda, iseenese $\sim$ iseenda kasutada ka genitiivi (Sõber ootas mind mu ära. Ta võttis end enda kokku). Üldreeglist erinevalt käituvad lisaks ka asesõnad mis ja kõik, põhiarvsõnad alates kahest, murdarvsõnad poolteist, veerand, kolmveerand ja pool, hulgasõnad nagu paar, paarsada, kümmekond, sadakond, mitu. (EKG II 1993: 53, Metslang 2017: 272) Järjekindlat vastavust sihitise üldreeglitega, sh aspektiga, ei ole $d a$-infinitiivi laiendaval objektil (nt soovib töölepingut töölepingu lõpetada) ning tõstetud objektil vat-tarindiga lauses (nt Peeter arvas Mardi õunu ostvat) (Ogren 2018, Erelt 2017a: 769, Liivak 2020). Infiniittarindite puhul ei sõltu objektikäände valik mitte niivõrd aspekti eristamisest, vaid on konstruktsioonipõhine. Selle nähtuse üks põhjustest on semantiline integratsioon (infiniitse lausega väljendatud olukorrad on omavahel seotud), mille puhul võivad puududa aja, aspekti, kõneviisi või isiku markeeringud (Cristofaro 2007: 107-108).

On täheldatud, et mõnel juhul ei erista ka finiitset verbivormi laiendava objekti käändevaheldus sisuliselt aspekti (nt Naine hoiab meest mehe tuhvli all) (vt Metslang 2017: 265). Tegevust võib lugeda nii piiritletuks kui ka piiritlematuks, kui tulemusseisund on ajutine (nt Keerasin lehe $\sim$ lehte ja lugesin edasi; Anna mulle pliiats pliiatsit) (EKG II 1993: 53, Leemets 2011: 56). Sellistes lausetes kasutatakse kvantitatiivselt piiritletud objektieseme korral nii totaal- kui ka partitiivobjekti, eelistatavalt viimast.

Sihitis võib järgida nii jaatava kui eitava lause vormivalikut, kui lause sisu ja vorm erinevad eitavuse-jaatavuse poolest. Kahtlevas, s.o eitamist oletavas jaatavavormilises väit- või küsilauses võib täissihitise asemel olla ka osastavaline sihitis (Vaevalt ta last lapse kaasa võtab; Kas ma sinu lugu sinu loo kaasa võtangi?), eitavavormilise kahtlusküsimuse puhul aga osastava asemel täissihitis (Me ütlesime: "Oo Jumala Sõnumitooja, kas me ei võiks sulle (korraliku) aseme teha?”). Täissihitis säilib jaatavas lauses mitte... vaid eituse korral (Eraettevõtja teatavasti kaotab mitte palga, vaid ettevõtte käibe ja selle kasumiosa!). (Metslang 2017: 268)

Lisaks olukorra piiritletuse-piiritlematuse vastandusele võib täissihitis toonitada objekti täielikku hõlmatust tegevuse või seisundiga (Aruanne sisaldab (kõoiki) andmeid $\sim$ kõik andmed eelmise aasta kulutuste kohta) ja kindlat kogust (Panin jäätist jäätise külmkappi) (Leemets 2011, Metslang 2017: 267-271).

Korpusematerjalis ilmnes muidki juhtumeid, kus objekti vormivalik ei allu alati piiritletud ja piiritlemata aspekti vastandusele. Nii kalduvad püsiühendid eelistama ühte käändevarianti, kas osastavalist (sai palka, pani pidurit, heitis peret) või 
täissihitist (nõudis ohvri). Sihitise käändevalik võib erineda polüseemse verbi tähendusvariantidel (vrd röövis meest ja röövis mehe; ületas tänavat tänava ja ületas kiirust).

Kirjeldatud juhtumid näitavad, et objekti käändevaheldus ei sõltu alati ega ainult piiritlusaspektist, vaid võib täita lauses ka muid funktsioone. Objekti käände valik kujuneb võistlevate ajendite (ingl competing motivations, Du Bois 1985) koostoimes, on $d a$-infitiivi laiendava objekti kohta järeldanud David Ogren (2018: 32). Sama ilmneb ka finiitse verbi puhul.

Kuivõrd aspekt - olgu siis verbi leksikaalsest tähendusest või lause kui terviku koosseisust tulenev - on objekti vormivahelduse keskne tegur, on siinses artiklis käsitatud aspektist sõltuvat vormivaheldust regulaarsena ja muudest teguritest sõltuvat ebaregulaarsena. Järgnevalt kirjeldatakse lähemalt mõlemat tüüpi vormivahelduse juhtumeid finiitse verbiga jaatavate lausete näitel.

\section{Regulaarne objekti käändevaheldus}

Regulaarseks võib nii seniste uurimuste kui korpusematerjali vaatluse põhjal pidada objekti vormivaheldust, mis toimub 1) ühetähenduslike või ühe objektirektsiooniga aspektverbide nagu ehitama, koostama puhul või polüseemse verbi kindla(te) tähendus(t)e puhul, 2) piiritlevate laiendite lisamist võimaldavate partitiivverbide puhul, 3) mõne partitiivverbi puhul objekti määratleva täiendi lisamisel, 4) piiritlemata olukorda iseloomustavate süntaktiliste elementide lisamisel perfektiivverbide puhul.

\subsection{Aspektverbi laiendav objekt}

Seda tüüpi käändevaheldust on grammatikates kõige rohkem kirjeldatud. Lisaks üldjuhul samalaadseid objekte võtvatele ühetähenduslikele või ühe objektirektsiooniga verbidele nagu ehitama, koostama, joonistama on aspektverbide hulka arvatud ka ka laiema semantikaga verbid nagu kirjutama, parandama, sööma, kutsuma, perfektiivse iseloomuga verbid nagu jätma, saavutama, avastama ja isegi tugiverbid saama ja võtma (EKG II 1993: 50-51, Erelt 2017c: 114, Metslang 2017: 264). Samas võib väita, et verbil on regulaarne objekti käändevaheldus vaid siis, kui tal on üks kindel tähendus või sama objektirektsiooniga tähendused, ta ei võimalda muid rektsioone ega haagi enda külge idiomaatilisi sihitisi (nt ehitama, koostama, joonistama: ehitas suvilat $\sim$ suvila, ehitas teooriat $\sim$ teooria, koostas aruannet $\sim$ aruande, koostas pikka rongi $\sim$ pika rongi, joonistas pilti $\sim$ pildi).

Polüseemsete verbide puhul võib objekti käändevaheldus ja selle regulaarsus sõltuda verbi tähendusnüanssidest või kasutusjuhtudest, mida vaatleme lähemalt aspektverbideks peetud tegusõnade kirjutama, sööma, parandama ja kutsuma näitel.

Verb kirjutama on kasutuses kahes peamises tähenduses: '(valmis) kirjutama' (1) ja 'välja kirjutama' (2), (3). Näites (1) on konkreetne piiritletud objekt, milleks on asjasõna artikkel, ning objekti käändevaheldus viitab reeglipäraselt kas piiritlemata või piiritletud olukorrale. Ka näites (2) on objekt piiritletud (komplektisõna) ning 
siin on ilma aspekti piiritlematusele viitava lausekontekstita (nt Kui arst mehele prille kirjutas..., mehele prille kirjutades jms) loomulik vaid totaalobjekt. Näites (3) on objektiks piiritlemata tähendusega sõna, osastavaline sihitis viitab siin objekti mittekonkreetsusele ja täissihitis sellele, et mõeldakse konkreetset ravimit. Tegevus on mõlemal juhul piiritletud. See tähendab, et teise tähenduse ('välja kirjutama') puhul on verbil kirjutama pigem perfektiivse verbi objektirektsioon nagu ka saavutama, avastama, jätma puhul (nt saavutas eesmärgi, avastas vea, jättis rahakoti koju).

(1) Teadlane kirjutas artiklit artikli.

(2) Arst kirjutas mehele prillid.

(3) Arst kirjutas haigele antibiootikume $\sim$ antibiootikumid, rohtu rohu.

Kirjutama tähendusega 'välja kirjutama' kaasneb latiivne valdajamäärus (2)-(3).

Verbi sööma puhul kasutatakse objektina tavaliselt ainesõnu (supp, puder jms) ning seepärast on sihitis enamasti osastavas (sõi suppi) ning totaalobjekti puhul kasutatakse reeglina perfektiivsusadverbi ära (sõi supi ära). Kui objektiks on asjasõna (nt võileib), siis on objekti käändevaheldus regulaarne (4).

(4) Söön hommikul võileiba võileiva ja joon kohvi.

Lisaks võib verbil sööma eristada ka perfektiivset (5) ja partitiivset (6) objektirektsiooni, kus viimase puhul on nii tegevus kui objekt piiritlemata.

(5) Lapsed sõid taldrikud tühjaks.

(6) Rooste sööb rauda.

Ka verbi parandama puhul esineb erinevaid objektirektsioone. Partitiivne rektsioon ilmneb näidetes (7), (8), (10) ja (11). Näites (7) on nii tegevus kui objekt piiritlemata, aga näites (8) on tegevus selgelt piiritletud, kuid objekt on partitiivis. Totaalobjekti kasutamiseks on vaja siin piiritlevaid laiendeid (9). Näidete nagu (10)-(11) puhul esineks loomulik totaalobjekt vaid perfektiivsusadverbi (parandas auto ära, parandas vihiku vihikud ära) või määratleva täiendi (vt 3.3) lisamisel. Näidetes (12)-(13) on objekti käändevaheldus regulaarne.

(7) On päris kindel, et naeratus parandab enesetunnet tunduvalt. (ENC17)

(8) Sportlane parandas oma rekordit.

(9) Sportlane parandas oma rekordi 10.02-ni.

(10) Isa parandas autot.

(11) Õpetaja parandas õpilase vihikut $\sim$ õpilaste vihikuid.

(12) Õpetaja parandas viga $\sim$ vigu.

(13) Õpetaja parandas vea (kõik) vead.

Verbi kutsuma puhul esineb partitiivne objektirektsioon tähenduses 'nimetama' (14) ja 'hüüdma' (15), perfektiivne rektsioon piiritlevate laiendite lisamisel (16)-(17) ja tähenduses'kohale kutsuma' (18).

(14) Rahvasuus kutsutakse halljänest ka haavikuemandaks ja kikk-kõrvaks. (ENC17)

(15) Emakaru kutsub poegi tavaliselt "mökitades". (ENC17)

(16) Kutsusin sõbra trenni ja kui saab, lähemegi üsna pea proovima. (ENC17) 
(17) Mees kutsuti kohtusse tunnistajaks.

(18) Kutsuti miilits ja sellest tuli paras jama. (ENC17)

Nagu nähtub toodud näidetest, sõltub polüseemsete verbide objektirektsioon ja sihitise vormivahelduse regulaarsus üsna sageli verbi tähendusvarjunditest. Viimastega võivad kaasneda erinevused lause argumentstruktuuris, näiteks sihitisele võib vastata teemaobjekt (kutsub jänest haavikuemandaks) või patsient (kutsub politsei sündmuspaigale). ${ }^{3}$ (Vt rohkem 4.3.)

Tugiverbidega püsiühendeid nagu haiget saama, kätt andma jms käsitletakse artikli osas 4.1. Nende puhul objekti käändevaheldus kas puudub või erineb üldreeglist.

\subsection{Partitiivverbi objekt piiritlevate laiendite lisamisel}

Mõned partitiivverbid, mis tähistavad aktiivset tegevust, käituvad lauses piiritlevate laiendite lisamisel aspekt- või perfektiivverbidena (vt Vaiss 2004: 65-71, Tamm, Vaiss 2019).

Latiivsel määrusel rajavas käändes on reeglina perfektiveeriv funktsioon, mis ei võimalda enam partitiivobjekti kasutamist (19), kuid nt verbi vähendama puhul on samasuguse perfektiveeriva funktsiooniga ka määrus saavas käändes (20).

(19) Sisekontrollisüsteem vähendab mïnimumini eksimuste ja vigade tekkimise võimaluse. $\left(\mathrm{ENC}_{17}\right)$

(20) Tasavägisele kohtumisele pani punkti Mihalis Kakiouzise korv viimasel sekundil, mis vähendas vahe kahepunktiliseks. (ENC17)

Teised separatiivsed või latiivsed määrused muudavad partitiivverbe üldjuhul aspektilisteks (21)-(29), kuid mõnikord ka perfektiivseteks (30).

(21) Poiss vaatas filmist vaid lõiku lõigu.

(22) Tüdruk luges jõuluvanale luuletust luuletuse.

(23) Mees saatis külalist külalise koju.

(24) Noormees aitas naist $\sim$ naise diivanile puhkama.

(25) Peremees harjutas kutsikat kutsika õues käima.

(26) Vanemad harjutasid last $\sim$ lapse iseseisvaks.

(27) Muusikud mängisid dirigendi tervituseks sonaati $\sim$ sonaadi.

(28) Õde ôppis emadepäevaks luuletust luuletuse.

(29) Kuulsin naabrilt head uudist $\sim$ hea uudise.

(30) Mees alandas hääle sosinaks.

Lisaks piiritlevatele laienditele loovad mõne partitiivverbi korral piiritlemisvõimaluse ka objektile lisatud täiendid, mida vaatleme osas 3.3.

3 Argumentide semantiliste rollide kohta vt Lindström, Taremaa 2013, Erelt 2017b: 68-76. 


\subsection{Partitiivverbi objekt määratleva täiendi lisamisel}

Mõned partitiivverbid võimaldavad regulaarset sihitise käändevaheldust, kui objektil on selle sisu määratlev täiend (vt Tamm, Vaiss 2019). See piirivõimaluse loomise viis võib olla ainus võimalus sihitise vormivahelduseks (31), esineda kombineeritult piiritlevate laienditega (32) või teise võimalusena piiritlevate laiendite kõrval (33), vrd (28).

(31) Orkester mängib nüüd veel ühe loo ühte lugu.

(32) Õde luges raamatust juttu lõvidest jutu lõvidest.

(33) Õde óppis pikka luuletust pika luuletuse.

Käändevaheldust võimaldavateks täienditeks on tavaliselt määratlejad üks ja oma, omadussõnad ja nimisõnalised täiendid elatiivis. Leidub ka näiteid ammendavat kogust tähistavate määratlejatega terve ja kogu, mille puhul on võimalik vaid totaalobjekt (34).

(34) Vend õppis terve $\sim$ kogu luuletuse.

\subsection{Perfektiivverbi objekt piiritlemata olukorrale viitavate süntaktiliste elementide lisamisel}

Mõne perfektiivverbi puhul võivad muuta perfektiivse tegevuse nagu (35) ja (36) piiritlematuks tegevuse eelfaasi väljendavad tarindid: mas-tarind (37) ja hakkamatarind (38). Samalaadselt toimivad ka ajalist hetke, kontinuatiivsust ja tegevuste üheajalisust märkivad määrsõnad ja sidendid parajasti, praegu, alati, pidevalt, just siis, kui...; sel hetkel, kui...; sel ajal, kui.. jms, vrd (39) ja (40) (vt ka Vaiss 2004: 72-73).

(35) Paraku oleme aga saavutanud kriitilise piiri, kus suur hulk politseinikke peab töötama lisakoormusega. (ENC17)

(36) Praegust statistikat vaadates tundub, et varsti saavutame oma eesmärgi.

(37) Erasõidukite arv Tallinnas on saavutamas ülemist piiri: rohkem lihtsalt ei mahu! (ENC17)

(38) --- praegust statistikat vaadates tundub, et hakkame oma eesmärki saavutama. (ENC17)

(39) Varem kaotas ta pidevalt oma prille.

(40) Ta kaotas oma prillid.

See käändevahelduse juhtum on teistega võrreldes nö kõige väiksema regulaarsusega, hõlmates mitmesuguseid grammatilisi ja leksikaalseid vahendeid. Samas viitab toodud näidetes partitiivobjekti kasutus selgelt piiritlemata kontekstile, seostudes aspektiga.

Järgmiseks vaatleme juhtumeid, kus objekti vormivalik ei ole tingitud alati aspekti eristamisest, vaid sõltub (ka) muudest teguritest. 


\section{Ebaregulaarne objekti käändevaheldus}

Ebaregulaarse käändevahelduse liikideks võib pidada 1) püsiühendi objekti eripärast tingitud käändevaheldust, 2) nn neutraalse aspekti juhtumeid, 3) verbi tähendusi eristavat ja 4) objektfraasi leksikaalsemantilisest koosseisust sõltuvat käändevaheldust.

\subsection{Püsiühendite objektid}

Püsiühendiks loetakse kahe või enama sõna(vormi) ühendit, mida on mingi tähenduse väljendamiseks tavaks koos kasutada. Kui ühendi osad esinevad koos oma tavatähendustes, kuid pole vabalt väljavahetavad, on tegu piiratud kollokatsiooniga (nt kehitab õlgu, kissitab silmi, liputab saba, vangutab pead). Kui verbi ja noomeni püsiühendi tähendus ei tulene otseselt seda moodustavate komponentide tähendustest, on tegu idioomiga (nt laseb jalga, peab lugu, ihub hammast), mida käsitletakse süntaksis ka väljendverbina. Väljendverb tingib lausemalli ning selle käändsõnaline komponent, mis on sageli partitiivis, ei allu objekti käändevahelduse reeglitele (?laseb jala), samuti ei saa seda modifitseerida (?laseb kïret jalga) ega muuta arvus (?laseb jalgu). Palju vähem leidub eesti keeles väljendverbe, mille nominaalne komponent võib muutuda objektikäänetes (kaarte avama, avab kaardid; käsi lööma, lööme käed). (Muischnek 2006a: 12-13, 17, 38-39, Rätsep 1978: 24-25)

Samuti leidub eesti keeles tugiverbiühendeid ehk verbi ja noomenifraasi ühendeid, milles laia tähendusega verb väljendab aega, isikut, tegumoodi jms ja seob lauset tervikuks, noomenifraas aga väljendab tegevust ja on lauses semantiliseks predikaadiks (Muischnek 2006a: 18), nt teeb füüsilist tööd, teeb pika hüppe, teeb otsuse, peab kõnet, peab pidu.

Kõige rohkem püsiühendeid moodustavad üldise tähendusega polüseemsed verbid nagu tegema, minema, panema, võtma, ajama, saama, andma, lööma, jääma, pidama (Muischnek 2006b: 53-54). Need verbid, v.a verb lööma, kuuluvad ka eesti keele tuumverbide hulka, mida kasutatakse grammatilistes funktsioonides ja/või mis väljendavad üldisi mõisteid (vt Tragel 2002, Pajusalu jt 2004).

Eesti keele verbikesksetes püsiühendites kõige sagedamini esinevad noomenid ( käsi, silm, pea, suu, süda, jalg, nahk, tee, nina, kõrv, ots, kael, hing, sõna, hammas, selg, nägu, keel, tuli, elu) väljendavad somaatilisi või muid nö inimlähedasi mõisteid. Somaatiliste sõnade kasutamine idiomaatilistes ühendites on keeltes levinud. Kõige rohkem kasutatakse eesti keele püsiühendites ainsuslikke käändsõnu; mitmuses esinevad eelkõige sõnad, mis tähistavad paariskehaosi (silmad, jalad, käed, kõrvad, õlad, huuled, mokad) ja hulka moodustavaid kehaosi (hambad, sõrmed, näpud, päkad, varbad). Mitmuses on ka sõnad lõug ja aju (nt laiutab lõugu, hoiab lõuad koomal, liigutab ajusid). Nominaalse komponendi käändena esineb enim partitiivi. (Muischnek 2006b: 54-55, 62-64, 68)

Korpuses leiduvad objektiga püsiühendid võib käändevalikust lähtudes jagada kahte rühma: 1) püsiühendid, mille vorm on niivõrd kinnistunud, et ei võimalda objekti käändevaheldust; tavaliselt on selliste ühendite tähendus kokku sulanud (nt hoolt kandma, meelt muutma, head tegema, haiget saama, haiget tegema,jänest 
sõitma, liblikat ujuma, sinasõprust jooma jms), 2) püsiühendid, mille puhul on võimalik objekti käändevaheldus, mis ei sõltu aga alati aspektist (nt selga pöörama, kätt andma, pead kaotama jms).

Nii esimesse kui ka teise rühma kuuluvad püsiühendid võivad olla mitmetähenduslikud. Näiteks on lauses (41) idiomaatilise püsiühendi tuld andma tähenduseks 'tulistama', mille puhul on erandlikult võimalikud ka ühendi nominaalse osa täiendid (nt andis kellegi pihta virtuaalset tuld). Lauses (42) on see püsiühend kasutatud juba ülekantud tähenduses 'püüdma kogu väest, kiirustama'. Näites (43) tähendab see pisut modifitseeritud kujul 'joostes ära minema' ning näites (44) 'suitsule tuld andma'. Ka struktuuri poolest sarnases maleväljendis igavest tuld andma on nominaalne osa alati partitiivis (45).

(41) Prokuratuur lükkab endiselt ümber väite, et koolimaja pihta anti tuld ka tankist. (ENC17)

(42) Andke tuld, ehitage nii kiiresti kui jaksate! (ENC17)

(43) Ehmatatud jänes andis jalgadele tuld. ( $\left.\mathrm{ENC1}_{17}\right)$

(44) "Anna tuld", "lähme teeme suitsu", "anna suitsu" on lisaks harjumusele sageli ka kadedaks tegev märguanne mahlakast loost, mis keelel kipitab. (ENC17)

(45) Garri Kasparovi ja malearvuti Deep Blue vahelise duelli viiendas partiis läks põnevaks alles lõppmängus, kui suurmeistri g-ettur jõudis eelviimasele reale. Maailma esimaletaja võidupunkti siiski ei teeninud, sest Deep Blue andis igavest tuld. ( $\left.\mathrm{ENC1}_{17}\right)$

Püsiühend rohelist tuld andma kuulub aga juba teise rühma, mille puhul on tavaline, et ühendi nominaalne osa on täissihitise vormis (46). Näites (47) on ühendi nominaalne osa partitiivis, mis osutab kas korduvale olukorrale või objekti ebamäärasusele.

(46) Paide andis rohelise tule uue lasteaia rajamiseks. (ENC17)

(47) Kord antakse rohelist tuld eraettevõtlusele, kord toimub pool-avalik riigistamine. ( $\left.\mathrm{ENC1}_{17}\right)$

Aspekti väljendamine pole alati primaarne ka selliste püsiühendite nagu selga pöörama korral, vrd (48)-(49) ja (50). Kui lausetes (48) ja (49) on esitatud tulemuslik tegevus, mistõttu selja pööramine ja genitiivne objekt on omavahel vastavuses, ükskõik kas püsiühendit kasutatakse otseses (48) või ülekantud tähenduses (49), siis lause (50) puhul ei saa väita, et tegevus on imperfektiivset laadi, ehkki on kasutatud objekti partitiivis. Võimalik, et põhjuseks on tegevuse mõtestamine ajutisena või irresultatiivsena.

(48) Mees pöörab selja ja jääb magama. (ENC17)

(49) Ametnikud pöörasid selja. (ENC17)

(50) Tema sõbranna mühatas ja pööras selga ning süvenes uuesti kleidi valimisse. (ENC17)

Lauses (51) on osastavaline sihitis aga õigustatud, kuna tänu imperfektiveerivatele süntaktilistele elementidele on tegevus korduv ja selgelt piiritlemata.

(51) Selg ja kael on koormatud, kui kummardutakse ettepoole või pööratakse selga või kaela korduvalt või pikema aja jooksul. (ENC17) 
Mõne püsiühendi nominaalset osa kasutatakse piiritletud aspektist sõltumata üldiselt partitiivis (52), (56) (ilmselt võetakse siin objektnoomenit tegevuse üldist sisu avava ainesõnana), kui pole lisatud piiritlevaid laiendeid (53), (57) või määratlevaid täiendeid (54), (55).

(52) Mina sain palka ja preemiat, need olid tolle aja kohta üle keskmise. (ENC17)

(53) Saime preemia raamatu "Üle majade" eest. (ENC17)

(54) Läbirääkimistel lubas ülemus, et saan küsitud palga siis, kui katseaeg läbi. (ENC17)

(55) Fremis sain sama palga, mis Aalborgis, aga pidin rohkem makse maksma. $\left(\mathrm{ENC}_{17}\right)$

(56) Panin pidurit ja auto tee äärde, vaatasin siis gepsust järgi, et kuhu kanti see Salla siis jääb. ( $\mathrm{ENC17})$

(57) Napsilembeste rottide joomakirg vähenes poole võrra, pärast seda kui neid oli nakatatud viirusega, mis pani piduri valgule, mis takistas alkoholi lagunemist. (ENC17)

Püsiühendi kätt andma korral võib partitiiv olla tavalisem lisaks aspekti ebamäärasusele ka tulemuse ajutisuse tõttu (58). Genitiivse objekti korral saab eristada eri tähendusi (59)-(63).

(58) Eeli tuli ise juurde, andis kätt ja küsis, kuidas tervis on! (ENC17) ('teretas kättpidi')

(59) Andsin käe ja tutvustasin ennast. (ENC17) ('teretasin kättpidi')

(60) Annaksin küll sellele mehele oma käe ja südame. ('nõustuksin abielluma')

(61) Andsin käe poliitikale. (ENC17) ('andsin end võimusesse')

(62) Ave andis käe, et aitab meie suuski määrida kolmapäeva õhtul. (ENC17) ('lubas')

(63) Andsin käe, ta haaras sellest kinni ja ma sikutasin tüdruku välja (ENC17) ('ulatasin käe', otsene tähendus)

Mõne verbi puhul on sõltuvalt kollokatiivse objekti iseloomust sihitise käändevaheldus kas võimalik (mängisime ühte mängu ühe mängu, orkester mängis veel ühte lugu ühe loo, mängiti veel ühte partiid üks partii jms) või välistatud (nt palli peitust mängima, kitarri viiulit mängima vms), vt 4.4.

\subsection{Neutraalne aspekt}

Sarnaselt aspekti ebamäärasusega mõnes püsiühendis, mida kirjeldasin osas 4.1, leidub eesti keeles üksikuid juhtumeid, kus aspekt pole selgelt ei piiritlemata ega piiritletud. Seda võib nimetada neutraalseks aspektiks, nagu näiteks verbi hoidma puhul (64) (vt Metslang 2017: 265).

(64) Ema hoidis last lapse haiguspuhangu ajal kodus.

Üksikud kestvat seisukorda väljendavad verbid, nagu sisaldama, säilitama, omama, moodustama, võlgnema, tagama, esinevad üldiselt kas totaalobjektiga 
(nt ta võlgnes mulle suure summa, see tagab mulle suure iseseisvuse) või osutab nende puhul sihitise käändevaheldus objekti terviklikkuse või mitteterviklikkuse suhtele (nt Raamat sisaldab vajalikke andmeid kõik vajalikud andmed) (vt Aavik 1936: 131, 306).

\subsection{Verbi tähendusi eristav käändevaheldus}

Leidub polüseemseid verbe, mille puhul eri tähendustega kaasneb erinev objektirektsioon (vt ka 3.1). Allpool on toodud mõned korpusematerjali põhjal konstrueeritud laused, mis näitavad, et verbide röövima, teenima ja võitma puhul saab objekti käändevaheldus eristada verbi tähendusi, vrd (65) ja (66), (67) ja (68), (69) ja (70).

(65) Vargad röövisid meest.

(66) Terroristid röövisid mehe.

(67) Mees teenis oma riiki.

(68) Mees teenis suure rahasumma.

(69) Sportlane võitis kuldmedali.

(70) Poiste korvpallikoondis võitis vastast 10 punktiga.

Kahes eri tähenduses esineb näiteks verb kaitsma. Kui kaitstakse kedagi või midagi vaenlase või ohtude eest nagu näidetes (71)-(73), on objekt partitiivis.

(71) Iga ema kaitseb oma last kõige halva eest.

(72) Advokaat kaitseb kohtus oma klienti.

(73) Sõdurid kaitsesid kindlust.

Kui aga kaitstakse teaduslikku tööd vms, siis on aspektipõhine objekti käändevaheldus võimalik, vrd (74) ja (75).

(74) Teadlane kaitses doktoritöö eelmisel aastal.

(75) Minu vend kaitseb teisipäeval magistritööd.

Niisiis pole polüseemsete verbide puhul objekti käändevaheldus alati regulaarne, vaid eristab verbi tähendusi. Verbil võib olla nii partitiivne kui perfektiivne tähendus (röövis meest, röövis mehe), nii partitiivne kui aspektiline tähendus (kaitseb oma last, kaitseb doktoritööd doktoritöö; ületas kïrust, ületas tänavat tänava), nii aspektiline kui perfektiivsema iseloomuga tähendus (kustutas tuld tule, kustutas võlad, failid). Nagu eespool mainitud (vt 3.1), võivad verbitähenduste erinevustega kaasneda sihitise erinevad semantilised rollid: teemaobjekt (röövis meest, kaitses kindlust) või patsient (röövis mehe, kaitses doktoritöö).

Mõnikord võib partitiivverbi kasutus totaalobjektiga olla tingitud konkreetse kõnesituatsiooni pragmaatikast. Näiteks ostu- ja müügiolukorras esineb kasutust nagu Sooviks veel ühe paki Malborot või Kas soovite veel ühe jäätise? Teistes kontekstides esineb verb soovima ikkagi partitiivobjektiga (76) (v.a sisaldusobjektiga kasutus (77)).

(76) Soovin pakki DPD kulleriga. (ENC17)

(77) Eemalt tuleb jooksuga põrsake ja karjub: "Puhh, Puhh, las ma soovin ka ühe soovi”? (ENC17) 


\subsection{Objektfraasi leksikaalsemantilisest koosseisust sõltuv käändevaheldus}

Esineb ka käändevahelduse erinevusi, mis sõltuvad ennekõike objektiks oleva noomenifraasi leksikaalsemantilisest koosseisust. Osalt põimuvad need juhud osades 3.1 ja 4.3 kirjeldatuga. Näiteks esineb verbi võitma ühe tähenduse puhul aspekti eristav käändevaheldus määratleva täiendi korral (78), kui objektnoomen selle lisamist võimaldab, vrd (79) ja (80).

(78) Poiste korvpallikoondis võitis tugevat vastast tugeva vastase.

$(79)=(70)$ Poiste korvpallikoondis võitis vastast 10 punktiga.

(80) Poiste korvpallikoondis võitis Soomet 10 punktiga.

Verbi ületama ühe tähenduse puhul on kïrus üldistatuna partitiivis (81), täpsema tähenduse korral on võimalik täissihitis (82)-(83).

(81) Autojuht ületas kiirust.

(82) Autojuht ületas lubatud kiirust lubatud kiiruse.

(83) Concorde'i kiirus küündis kuni 2170 kilomeetrini tunnis, mis ületab helikiiruse umbes kaks korda. (ENC17)

Kui võrrelda aga näiteks tänava ja valimiskünnise ületamist, siis tänava ületamist võib vaadelda nii kestva kui resultatiivsena (84), valimiskünnise ületamist aga pigem kohe tulemuslikuna (85).

(84) Mees ületas tänavat tänava.

(85) Erakond ületas valimiskünnise.

Verbi aktsepteerima puhul sõltub objekti käändevaheldus küll verbi tähenduste nüanssidest ('heaks kiitma', 'kinnitama'), kuid need pole alati selgelt eristatavad ning tundub, et olulist rolli mängib siin pigem objekti leksikaaltähendus. Üldiselt kasutatakse verbi aktsepteerima partitiivobjektiga (86)-(88), kuid juhul, kui aktsepteeritakse mõnda dokumenti või ettepanekut, kasutatakse ka totaalobjekti (89)-(90).

(86) Kui seda ettepanekut aktsepteeritakse, siis alustame uuesti arutelu järgmisel aastal ning vajaduse korral teeme hääletuse. (ENC17)

(87) Naine aktsepteeris mehe otsust ning lubas ka endal eluga edasi minna. ( $\mathrm{ENC17})$

(88) Seni, kuni pere aktsepteerib meest ja isa sellisena nagu ta on, siis ongi kõik hästi. (ENC17)

(89) Juhatus on seda meelt, et kuna komisjon asendajat ei leidnud, siis juhatus aktsepteerib ettepaneku ja ma loodan, et ka teie, kolleegid. (ENC17)

(90) Maksuamet aktsepteeris taotluse. (ENC17)

Sama verbi puhul on võimalik totaalobjekt ka siis, kui piiritletuna võetav sihitis on esile tõstetud umbisikulise lause teemasse, vrd (91) ja (92).

(91) Tulemused aktsepteeriti.

(92) Aktsepteeriti tulemusi. 
Kui aktsepteeritakse kaardimakset, krediitkaarti või ID-kaarti, siis kasutatakse tavaliselt partitiivobjekti (93), ehkki tegevus tundub selgelt piiritletuna.

(93) Hotell aktsepteeris minu krediitkaarti.

Seega on nii mõnedki objekti käändevahelduse juhtumid palju keerulisemad ja ennustamatumad, kui eeldavad jaatava lause objekti ja/ või tegevuse piiritletuse markeerimisel põhinevad sihitisereeglid. Oma mõju on vormi kinnistumisel püsiühendites, verbi, objektieseme ja kogu ühendi tähendusel, lause infostruktuuril, aspektivastanduse neutraliseerumisel, kontekstil ja suhtlussituatsioonil.

Lisaks kajastab mitteregulaarset objekti käändevaheldust korpuses esindatud keelekasutus, kus esineb verbirektsiooni nihkeid. Neid juhte vaatlemejärgmises osas.

\section{Korpuses esinevad objektirektsiooni nihked}

Mati Hint (2017) on juhtinud tähelepanu eesti keeles arenevale tendentsile, et osastav on justkui muutumas üldiseks objektikäändeks (akusatiiviks), kuna seda kasutatakse üha sagedamini täissihitise käänete asemel, eriti kõnekeeles ja spontaanses kõnes. Ühe põhjusena, miks aspekti väljendumine objektikäände abil on ähmastumas, perfektiivsusadverbide kasutamine aga laienemas, nimetab Hint (2017: 162) indoeuroopa keelte üldist kombineeritud mõju.

Tänapäeva korpusest on näha ka vastupidist tendentsi: totaalobjekti kasutust partitiivobjekti asemel. Näidetes (94)-(98) on näha lähedase tähendusega verbi aspektuaalsuse ülekandmist.

(94) Mees koges oma elu suurima vapustuse. (< sai) (ENC17)

(95) Kurtke oma mured ja me leiame lahenduse. (< rääkige) (ENC17)

(96) Nutikad baarmenid tarvitavad ühe munavalge kaheks joogiks. $(<$ kulutavad) (ENC17)

(97) Küüditatuna pidi ta taluma 15 aastat raskeid ja ebainimlikke vintsutusi Venemaal, mis kahjustasid tema tervise jäädavalt. (< rikkusid) (ENC17)

(98) Kriminaalmenetlus alustati paragrahvi alusel, mis käsitleb teenistusalast hooletust. (< algatati) $\left(\mathrm{ENC1}_{17}\right)$

Mõne partitiivverbi puhul leidub korpuses mitmeid näiteid totaalobjektiga (nt kahjustama ja alustama puhul), mis võib olla märgiks, et nende verbide rektsioonid ongi muutumas. Samas tähistab selline sihitis sageli tuntud referenti, on vormilt liitsõna või vähemalt kahest sõnast koosnev nimisõnafraas, mis esitab objekti konkretiseerituna - see võib kasutajale anda põhjust totaalobjekti kasutuseks sarnaselt osas 3.3 kirjeldatuga. Näiteks lauset (99) pidasid kõik minu küsitletud emakeelsed kõnelejad vastuvõetavaks, kuna lausega rõhutatakse alustamise momenti ning selle vastuvõtjale peaks olema teada, millisest sõjast on juttu.

(99) Kes vajutas nuppu, mis alustas sõja? (ENC17)

Kui Hint (2017) osutab perfektiivsusadverbide rohkele kasutusele, siis jällegi hakkab korpuses silma vastupidine tendents: rohkelt näiteid, kus ühend- või väljendverbi asemel kasutatakse lihtverbi koos perfektiivsusele viitava täissihitisega (100)-(102). 
(100) Meie pakume sellise lahenduse, et üks laps toob kaasa 1000 krooni tulumaksuvabastuse. ('pakume välja') (ENC17)

(101) Või mõtleme mingi muu variandi. ('mõtleme välja') (ENC17)

(102) Proovige mõlemad kingad. ('proovige jalga') (ENC17)

Esitatud näidetega sarnaste korpuselausete vaatlus võimaldab väita, et tänapäeva eesti keeles on märgata kahte tendentsi: 1) kasutada aktiivset tegevust võimaldavaid partitiivverbe aspektverbidena, kui sihitise positsioonis on nimisõnafraas või kõneleja peab silmas konkreetset või tuntud objekti; 2) kasutada ühend- ja väljendverbide asemel lihtverbe (seega keele analüütilisuse vähenemist, vt ka Metslang 2019: 113-114).

Järgmises osas peatume kahe verbi kasutusel korpuses, et näidata, millistest tähendus- ja kasutusnüanssidest võib sõltuda objektikäände valik. Vaatluse all on partitiivverb hammustama ja perfektiivse tähendusega verb ostma.

\section{Partiiv- ja perfektiivverbi kasutus eesti keele ühendkorpuse näitel: hammustama ja ostma}

\section{1. hammustama}

"Eesti keele grammatika" järgi kuulub verb hammustama liigutamist ja puudutamist väljendavate partitiivverbide hulka (103).

(103) Kui vend õde lõi, hammustas see tal kätt. (EKG II 1993: 50)

Samas on hammustama verb toodud ka näiteks, kui mainitakse, et "tegevust sisemiselt piiravat funktsiooni” võivad lauses täita latiivsed piiritlejad (104). (EKG II 1993: 50-51).

(104) Õde hammustas niiti niidi katki puruks. (EKG II 1993: 51)

Huno Rätsepa käsitluses (1978) on hammustama kahesuguse objektikasutusega verb (105)-(106).

(105) Koer hammustas teekäijat säärest säärde. (Rätsep 1978: 85, 86)

(106) Hai hammustab endale looma küljest tüki. (Rätsep 1978: 176)

Kui vaatame verbi hammustama esinemist korpuses, siis näeme järgmisi levinud transitiivseid kasutusi (107)-(112), mis on vastavuses eesti keele seletavas sõnaraamatus (EKSS) toodud tähendustega.

(107) Ai, praegu hammustas üks sääsk minu kätt! (ENC17)

(108) Professor hammustas huult ja ohkas. (ENC17)

(109) Lumi vingub jala all ja pakane hammustab põski. (ENC17)

(110) Hai hammustas Jessielt käe, kui poiss oli mängimas madalas vees Florida rannikul. (ENC17)

(111) Jõin mittemidagiütleva näoga oma kohvi ja hammustasin võileiba. (ENC17)

(112) Hammustasin suure tüki, kuid siiski olen reaalne ja pisikesed vaheeesmärgid on ikka seatud. (ENC17) 
Lausega (107) on kirjeldatud ühekordset tulemuslikku ehk aspektilt piiritletud olukorda ning kuna hammustama on partitiivverb, on kasutatud sihitist partitiivis. See on tegelikult sarnane püsiühendite sihitisega (nt ta pani pidurit), kus aspektitähendus ja objektikääne ei ole vastavuses (vt 4.1). Lausega (108) väljendatud tegevus võib olla nii ühe- kui ka mitmekordne, sihitis on partitiivis, kasutatud on püsiühendit. Lauses (109) on verbi hammustama kasutatud ülekantud tähenduses ning kirjeldatud tegevus on selgelt piiritlemata ehk imperfektiivne. Lauses (110) on objekt totaalne tänu separatiivsele laiendile (Jessielt) ning verbi tähenduseks on siin juba 'otsast ära hammustama', 'hammaste abil eraldama'. Lauses (111) on verbi hammustama kasutatud tähenduses 'sööma', 'närima' ning tegevus on piiritlemata. Lauses (112) on tähenduse 'otsast ära hammustama', 'hammaste abil eraldama' idiomaatiline kasutus, totaalobjekti soodustab ka asjaolu, et objektiks on määratleva täiendiga nimisõnafraas suur tükk.

Niisiis kasutatakse verbi hammustama põhiliselt kahes imperfektiivses tähenduses - 1) 'kedagi (või mingit kehaosa) ühekordselt või mitmekordselt hammustama' ehk 'hambaid sisse suruma või kokku pigistama', piltlikult ka 'külma- või valutunnet tekitama', 2) 'sööma', 'närima' - ja ühes perfektiivses tähenduses 'otsast ära hammustama', 'hammaste abil eraldama'. (Lisaks võib ka kedagi veriseks või surnuks hammustada, midagi katki, pooleks või puruks hammustada, need aga on juba perfektiivse iseloomuga analüütilised verbid.)

\section{2. ostma}

Võib eeldada, et ostma on perfektiivne verb, kuna selle tähenduses esildub tegevuse tulemuslikkus, mitte kestmine.

Rätsepal (1978) on verbile ostma antud 3 illustreerivat näidet (113)-(115). Lausetes (113) ja (114) on sihitis genitiivis; fakultatiivsed on nende lausete puhul separatiivne kohamäärus, latiivne (113) ja separatiivne valdajamäärus (114). Lausega (115) on mas-tarindi abil väljendatud imperfektiivne olukord, mistõttu sihitis on partitiivis.

(113) Peeter ostis tütrele Tallinnast raamatu. (Rätsep 1978: 112)

(114) Andres ostis mõisnikult talukoha. (Rätsep 1978: 112)

(115) Jaan oli poes üksinda kingi ostmas. (Rätsep 1978: 193)

Jälgides verbi ostma esinemist korpuses võib märgata, et seda laiendav sihitis on objektieseme piiritlematuse tõttu sageli partitiivis: ostetakse toitu, riideid, raamatuid, (eba)vajalikke asju jms. Kui jaatava lause sihitise rollis on konkreetne, piiritletud objekt, siis on see tavaliselt totaalne. Verbi ostma puhul säilib totaalobjekt ka olevikulise korduva tegevuse puhul (vt Aavik 1936: 131). Nii on korpuselausetega (116) ja (117) väljendatud korduv olukord, mille iga üksikjuht on oma olemuselt tulemuslik. Kui tuleks tõlkida need laused vene keelde, siis peaks kasutama imperfektiivse aspektiga verbi pokupat'.

(116) Iga kahekümnes ostab eluaseme laenuta. ( $\mathrm{ENC17}$

(117) Ma ostan iga päev uue paki (küpsiseid). (ENC17) 
Samas on ostma ja piiritletud objekti puhul võimalik ka sihitis partitiivis (118)(120), kuid selleks on vaja kindlat imperfektiivset konteksti, mida lisatakse erinevate süntaktiliste elementide abil (nt igal hommikul, pidevalt, mas-tarind jms).

(118) Üks tuttav ajakirjanik ka juba jubeammu mulle rääkis, kuidas ta Päevalehte ja Postimeest ostab igal hommikul --- (ENC17)

(119) Kahjuks on paljud selle rõõmsalt vastu võtnud, ostavadki pidevalt Kroonikat, vaatavad tõsielusarju ja tähtedega laulmist-tantsimist, tormavad Valduri ja Maie kontserdile ning otsivad kirglikult koos Eestiga superstaari. (ENC17)

(120) Olin pühapäeval Rocca al Mare lõbustuspargi keskmise kassa ees piletit ostmas. (ENC17)

Püsiväljendi põrsast kotis ostma puhul on jaatavas väitlauses tavaline totaalobjekt (121), (122). Eitust eelistava kahtlusküsimusega näites (123) on partitiivobjekt nagu eitavas lauses.

(121) Loll, kes põrsa kotis ostab! (ENC17)

(122) Tunnen, et olen põrsa kotis ostnud. (ENC17)

(123) Kes põrsast kotis ostab? (ENC17)

Vaadeldud näited kinnitavad, et verbide jaotumine partitiiv-, aspekt- ja perfektiivverbideks on mõnevõrra tinglik, kuna süntaktilise käitumise põhjal peaksid kõik objekti käändevaheldust võimaldavad verbid aspektverbide alla kuuluma. Samas ei anna midagi pelk teadmine, et sellised verbid nagu hammustama ja ostma võimaldavad nii täis- kui osastavalist sihitist. Võistlevate ajendite koostoimet tuleb vaadata igal konkreetsel juhul eraldi.

\section{Kokkuvõtteid ja järeldusi}

Kuigi sihitise käändevaheldus on üks eesti keele eripäraseid jooni, ei tunne me selle tegureid veel kuigi põhjalikult. Põhireegli kohaselt sõltub finiitset verbivormi laiendava sihitise käändevormi valik neljast tegurist: 1) kas lause on jaatav, 2) kas objekt on piiritletud ega pole erandlik (nt isikuline asesõna, kvantorifraas), 3) kas tegevus on piiritletud ja mis tüüpi on verb(itähendus) - partitiivne, aspektiline või perfektiivne, ning 4) milline on verbi grammatiline vorm. Teame, et infiniittarindiga seostumisel on partitiiv- ja totaalobjekti vastandus kõikuv (Ogren 2018, Liivak 2020). Rikkalik korpusematerjal viitab aga sellele, et ka finiitse verbi puhul võivad lisaks üldtuntud teguritele mängida rolli mitmed muudki asjaolud.

Artiklis on objekti käändevaheldus jaotatud regulaarseks (aspekti eristavaks) ja ebaregulaarseks (muudest teguritest sõltuvaks); mõlemat tüüpi on kirjeldatud korpusematerjali põhjal. Ilmneb, et partitiiv- ja totaalobjekti vastandus võib mitte ainult osutada piiritletud ja piiritlemata aspekti või terviku ja osa opositsioonile, vaid ka eristada tähendusi, sõltuda kontekstist, sõnajärjest, lause infostruktuurist, väljendi pragmaatikast vm.

Päris suurel osal eesti keele verbidest on mitu tähendust või tähendusvarjundit, mille puhul esineb erisugune objektikäände rektsioon. Autori varasema uurimuse kohaselt oli 509 analüüsitud lihtverbi hulgas 145 (ehk 28,5\%) mitmetähenduslikku 
verbi objektikäände eri rektsioonidega (Vaiss 2004: 65). Tegelikkuses võib nende verbide osakaal osutuda palju suuremaks, kuna paljude verbide puhul võib isegi väga väike tähendusnüanss muuta objektikäände rektsiooni.

Transitiivsete verbide traditsiooniline jaotamine partitiiv-, aspekt- ja perfektiivverbideks on tinglik, kuna paljude partitiiv-ja perfektiivverbide puhul on teatud tingimustel võimalik sihitise vormivaheldus. Üsna paljud eesti keele verbid on polüseemsed ning objektirektsiooni tuleb sageli vaadata verbi tähendusest lähtuvalt. Võimalik lahendus liigituse jaoks oleks kas lugeda kõik objekti käändevaheldust võimaldavad verbid aspektverbideks, millest aga kujuneks väga heterogeenne klass, või siis eristada siirderühmi iga verbitüübi juures.

Partitiivobjekti kasutuse laienemist (Hint 2017), lihtverbi kasutust analüütiliste verbide asemel ja totaalobjekti kasutust partitiivverbide puhul võiks pidada keelekasutuses käimas olevateks niheteks. Samas selleks, et saaks toimunud või toimuvatest muutustest põhjendatult rääkida, on vaja ulatuslikke diakroonilisi ja sünkroonilisi uurimusi. Võimalik on varieerumine ka registrite lõikes. On täheldatud erinevusi suulise ja kirjaliku keele vahel; lisaks on kujunemas netikeel, mis ühendab mõlemat ja loob oma tendentse.

Sihitise käändevahelduse tegurite paljusus teeb sihitisest keeruka teema keeleteaduse rakenduste jaoks. Eesti keele kui teise või võõrkeele kõneleja vajab võimalust leida infot sagedasemate verbide objektirektsioonide kohta. Mingil määral on see juba praegu võimalik sihitisesõnastikust (SS), kus leiduvad 400 verbi objektirektsioonid. Ka eesti keele kui teise keele õppes on viimasel ajal loodud materjale, kus sihitise reeglite esitamisel on verbikeskne lähenemine (Kitsnik 2019, Käänuk). Sihitise problemaatika uurimine jätkub, andes uut teadmist eesti keele kasutusest nii keelekirjeldusele kui keeleteaduse rakendustele.

\section{Kirjandus}

Aavik, Johannes 1936. Eesti õigekeelsuse õpik ja grammatika ['Estonian Textbook and Grammar']. Tartu: Noor-Eesti Kirjastus.

Askonen, Ebba 2001. Objektin aspektuaalinen sijanvalinta ['Aspectual Choice of the Object Case']. Oulun yliopiston suomen ja saamen kielen ja logopedian laitoksen julkaisuja 19. Oulu: Oulun yliopisto.

Cristofaro, Sonia 2007. Deconstructing categories: Finiteness in a functional-typological perspective. - Irina Nikolaeva (Ed.), Finiteness: Theoretical and Empirical Foundations. Oxford: Oxford University Press, 91-114.

Du Bois, John 1985. Competing motivations. - John Haiman (Ed.), Iconicity in Syntax. Typological Studies in Language 6. Amsterdam: Benjamins, 343-366. https://doi. org/10.1075/tsl.6.17dub

EKG II = Erelt, Mati; Kasik, Reet; Metslang, Helle; Rajandi, Henno; Ross, Kristiina; Saari, Henn; Tael, Kaja; Vare, Silvi 1993. Eesti keele grammatika II. Süntaks. Lisa: kiri ['The Grammar of the Estonian Language II: Syntax']. Tallinn: ETA Keele ja Kirjanduse Instituut.

Erelt, Mati 2017a. Sekundaartarinditega laused ['Sentences with secondary constructions']. Mati Erelt, Helle Metslang (Toim.), Eesti keele süntaks. Eesti keele varamu III. Tartu: Tartu Ülikooli Kirjastus, 756-840.

Erelt, Mati 2017b. Sissejuhatus süntaksisse ['Introduction to syntax']. - Mati Erelt, Helle Metslang (Toim.), Eesti keele süntaks. Eesti keele varamu III. Tartu: Tartu Ülikooli Kirjastus, 53-89. 
Erelt, Mati 2017c. Öeldis ['Predicate']. - Mati Erelt, Helle Metslang (Toim.), Eesti keele süntaks. Eesti keele varamu III. Tartu: Tartu Ülikooli Kirjastus, 93-239.

Eslon, Pille 2012. Objekti ja tegevuse leksikaalne markeeritus eesti óppijakeeles ['The lexical markedness of object and action in Estonian learner language']. - Lähivõrdlusi. Lähivertailuja, 22, 15-42. https://doi.org/10.5128/LV22.01

Hint, Mati 2017. Partitiivi laienemine aspektituks objektikäändeks ['Expansion of partitive case in the Estonian language into a counterpart of Indo-European accusative']. Mäetagused, 69, 153-180. https://doi.org/10.7592/MT2017.69.hint

Kilgarriff, Adam; Rychly, Pavel; Smrz, Pavel; Tugwell, David 2004. The Sketch Engine. G. Williams, S. Vessier (Eds.), Proceedings of the XI Euralex International Congress. Lorient: Université de Bretagne Sud, 105-116.

Kitsnik, Mare 2019. Sõnajalaõis. Gümnaasiumi eesti keele kui teise keele õpik ['Estonian as a Second Language Textbook for Gymnasium. Part 1']. 1. osa. Koolibri.

Klaas, Birute 1999. Dependence of the object case on the semantics of the verb in Estonian, Finnish, and Lithuanian. - Mati Erelt (Ed.), Estonian: Typological Studies III. Tartu: University of Tartu, 47-83.

Leemets, Tiina 2011. Mida küsitakse keelenõuandjailt sihitise kohta? ['What are language advisors asked about object?'] - Oma Keel, 22, 55-61.

Levin, Beth 1993. English Verb Classes and Alternations. Chicago: University of Chicago Press.

Liivak, Mirjam 2020. Tõstetud objekti vorm vat-tarindiga lausetes ['The form of the raised object in the sentences with vat-construction']. Bakalaureusetöö. Tartu: Tartu Ülikool. http://hdl.handle.net/10062/67895

Lindström, Liina; Taremaa, Piia 2013. Semantilised rollid keeleuurimise vahendina ['Semantic roles as a linguistic tool']. - ESUKA/JEFUL, 4, 35-52. https://doi.org/10.12697/ jeful.2013.4.1.03

Metslang, Helle 2017. Sihitis ['Object']. - Mati Erelt, Helle Metslang (Toim.), Eesti keele süntaks. Eesti keele varamu III. Tartu: Tartu Ülikooli Kirjastus, 258-277.

Metslang, Helle 2019. Eesti kirjakeele arenguteelt: grammatikamuutuste sammud ja hüpped ['On the development of the Estonian written language: Steps and leaps in grammar changes']. - Riho Altnurme (Toim.), Humanitaarteadused ja kunstid 100-aastases rahvusülikoolis. Tartu: Tartu Ülikooli kirjastus, 102-119

Muischnek, Kadri 2006a. Verbi ja noomeni püsiühendid eesti keeles ['Fixed Expressions Consisting of Verbs and Nouns in Estonian']. Dissertationes Philologiae Estonicae Universitatis Tartuensis 17. Tartu: Tartu Ülikooli Kirjastus.

Muischnek, Kadri 2006b. Eesti keele verbikesksete püsiühendite nominaalsetest komponentidest ['On the nominal components of the verbal-based fixed expressions in Estonian']. - Mare Koit, Renate Pajusalu, Haldur Õim (Toim.), Keel ja arvuti. Tartu Ülikooli üldkeeleteaduse õppetooli toimetised, 6. Tartu: Tartu Ülikooli Kirjastus, 51-71.

Nemvalts, Peep 2000. Aluse sisu ja vorm. Alusfraasi käändevaheldus tänapäeva eesti kirjakeeles ['On the Content and Form of the Subject']. Tallinn: Eesti Keele Sihtasutus.

Ogren, David 2018. Object case variation in Estonian $d a$-infinitive constructions. Dissertationes Philologiae Estonicae Universitatis Tartuensis 41. Tartu: University of Tartu Press.

Pajusalu, Renate; Tragel, Ilona; Veismann, Ann; Vija, Maigi 2004. Tuumsõnade semantikat ja pragmaatikat ['Semantics and Pragmatics of Core Words']. Tartu Ülikooli üldkeeleteaduse õppetooli toimetised 5. Tartu: Tartu Ülikooli Kirjastus.

Pihlak, Ants 1985. Tähelepanekuid kursiivsusest ja terminatiivsusest eesti keeles ['Observations on coursivity and terminativity in Estonian']. - Keel ja Kirjandus, 3, 149-158.

Pool, Raili 2007. Eesti keele teise keelena omandamise seaduspärasusi täis- ja osasihitise näitel ['The Acquisition of Total and Partial Objects by Learners of Estonian as a Second Language']. Dissertationes Philologiae Estonicae Universitatis Tartuensis 19. Tartu: Tartu Ülikooli Kirjastus. 
Rätsep, Huno 1978. Eesti keele lihtlausete tüübid ['Types of Simple Sentences in Estonian’]. Tallinn: Valgus.

Tamm, Anne 2012. Scalar Verb Classes: Scalarity, Thematic Roles, and Arguments in the Estonian Aspectual Lexicon. Firenze: Firenze University Press. https://doi. org/10.36253/978-88-6655-055-6

Tamm, Anne; Vaiss, Natalia 2019. Setting the boundaries: Partitive verbs in Estonian verb classifications. - Eesti Rakenduslingvistika Ühingu aastaraamat, 15, 159-181. https:// doi.org/10.5128/ERYa15.09

Tauli, Valter 1980. Eesti grammatika II. Lauseõpetus ['The Grammar of the Estonian Language II: Syntax']. Uppsala: Finsk-ugriska institutionen.

Tommola, Hannu 1986. Аспектуальность в финском и русском языках [“Aspectuality in Finnish and Russian']. Neuvostoliitoinstituutin vuosikirja 28. Helsinki.

Tragel, Ilona 2002. On Estonian core verbs. - I. Tragel (Ed.), Papers in Estonian Cognitive Linguistics. Tartu Ülikooli üldkeeleteaduse õppetooli toimetised 2. Tartu, 145-169.

Tragel, Ilona; Taremaa, Piia 2019. Eesti keele verbide semantilisest liigitamisest ['Semantic classification of Estonian verbs']. - Keel ja Kirjandus, 3, 207-222.

Vaiss, Natalia 2004. Eesti keele aspekti väljendusvõimalusi vene keele taustal ['The Expression of Aspect in Estonian in Comparison with Russian']. Magistritöö. Tallinn: Tallinna Pedagoogikaülikool. http://hdl.handle.net/10062/44143

Van Valin, Robert D. 2005. Exploring the Syntax-Semantics Interface. Cambridge: Cambridge University Press. https://doi.org/10.1017/CBO9780511610578.001

Vendler, Zeno 1967. Linguistics in Philosophy. Ithaca: Cornell University Press.

\section{Võrgumaterjalid}

EKSS = Eesti keele seletav sõnaraamat 2009. http://www.eki.ee/dict/ekss (1.10.2019).

ENC17 = Kallas, Jelena; Koppel, Kristina 2018. Eesti keele ühendkorpus 2017 ['Estonian National Corpus 2017']. Center of Estonian Language Resources. https://doi. org/10.15155/3-00-0000-0000-0000-071E7L

ENC19 = Kallas, Jelena; Koppel, Kristina 2020. Eesti keele ühendkorpus 2019 ['Estonian National Corpus 2019']. Center of Estonian Language Resources. https://doi. org/10.15155/3-00-0000-0000-0000-08489L

$\mathrm{SS}=$ Sihitisesõnastik 2019 ['Direct Object Dictionary']. http://www.eki.ee/dict/asp (1.10.2019). Käänuk ['Browser game "Käänuk”]. http://k44nuk.ee (1.10.2019). 


\title{
ESTONIAN TRANSITIVE VERBS FACING CHOICES
}

\author{
Natalia Vaiss \\ Institute of the Estonian Language, Tallinn University
}

Estonian transitive verbs are traditionally divided into partitive, aspect, and perfective verbs. While the classic definitions state that partitive verbs are to express imperfective aspect and to be applied with partitive objects only, and perfective verbs to appear with total objects in genitive or nominative cases, both verb types may allow differentional object case alternation (DOM) under certain circumstances. Object case alternation could be seen as regular (or distinguishing aspect) and non-regular (e.g., differentiating meanings of a verb, depending on context, object features, 'neutral' aspect, or the structure of a fixed expression). All these cases are analysed in the article based on the Estonian National Corpus 2017 materials.

Keywords: aspect, transitivity, object, Estonian

Natalia Vaiss (Eesti Keele Instituut, Tallinna Ülikool) uurib eesti keele verbide transitiivsuse määra, aspekti väljendusvõimalusi eesti keeles ning verbisemantikast tulenevat objekti käändevaheldust. Roosikrantsi 6, 10119 Tallinn, Estonia

natalia.vaiss@gmail.com 